\title{
Spatial and Temporal Dynamics of Anabaena flos-aquae Akinetes in Bottom Sediments of a Small Siberian Reservoir
}

\author{
Elena S. Kravchuk ${ }^{\text {a* }}$ and Elena A. Ivanova ${ }^{a, b}$ \\ a Institute of Biophysics of Siberian Branch of Russian Academy of Sciences, \\ Akademgorodok, Krasnoyarsk, 660036 Russia \\ ${ }^{b}$ Siberian Federal University, \\ 79 Svobodny, Krasnoyarsk, 660041 Russia $^{1}$
}

Received 1.06.2009, received in revised form 8.06.2009, accepted 15.06.2009

Spatial distribution of akinetes of Anabaena flos-aquae (cyanobacteria) in littoral bottom sediments of a small Siberian reservoir was studied. Akinete abundance in bottom sediments is found to be related with type of sediments and presence of higher water plants. The highest abundance of akinetes was observed in silty sediments at stations located in higher plants bed (mainly emerged plants Typha latifolia L. and Phragmites australis (Cav.) Trin. ex Steud.). These results demonstrate that macrophyte beds could increase the size of the potential cyanobacterial inoculum by accumulation of akinetes in shallow bottom sediments and, as a result, favour cyanobacterial bloom development. In addition, seasonal dynamics of Anabaena flos-aquae, including vegetative cells and akinetes, in bottom sediments and water column in open water and littoral of the reservoir was studied. Dynamics of Anabaena abundance in the water column at the central station and littoral stations were very similar, but the number of cells in the littoral achieved higher year maximum than that at the central station. The highest seasonal peak of vegetative cells and akinetes in the water column was observed at the littoral station, located in emerged higher plants bed. However, at this part of the reservoir lowest intensity of akinete production was recorded. Deposition of akinetes to bottom sediments occurred both in open water and littoral. Nevertheless, seasonal dynamics of akinetes in bottom sediments differed between these sites. At the central station accumulation of akinetes in bottom sediments occurred throughout the summer, but in the littoral abundance of akinetes decreased just after their sedimentation. Hence, abundance of akinetes in the littoral sediments of the reservoir is markedly lower than that in the deeper central part.

Keywords: Cyanobacteria, akinetes, resting stages, water bloom

\section{Introduction}

Harmful freshwater cyanobacterial blooms is an increasing problem that impact human and animal health, water quality and recreation (Paerl et al., 2001). Many bloom-forming cyanobacteria during unfavorable growth conditions persist in bottom sediments as resting stages (akinetes or dormant colonies). Importance of migration of the resting stages from the sediments for development of planktonic populations is still debatable. However, in some cases resting stages in bottom sediments represent potentially significant inocula for subsequent development of pelagic populations (Baker, 1999; Head et al.,

* Corresponding author E-mail address: kravchuk@ibp.krasn.ru

(C) Siberian Federal University. All rights reserved 
1999). It was found (Sirenko, 1978; Tsujimura et al., 2000), that the time of bloom formation is related to the quantity of Microcystis colonies in the sediment, i.e. if the quantity of new inoculum from the sediment is very large, the bloom will be formed earlier. Tsujimura and Okubo (2003) also presumed that the probability of bloom formation will be enhanced by the extent of sediment inoculations, since in the water column species which have benthic (resting) stage may have a competitive advantage over those species which do not. It was shown that there is relation between number of resting stages in bottom sediments and extent of Anabaena flos-aquae (Lyngb.) Breb. predominance in phytoplankton community (Kravchuk et al., 2007).

The littoral was found to be the main site for recruitment of cyanobacteria, probably due to higher temperature, more light, and more sediment mixing than at profundal sites (Head et al., 1999; Karlsson-Elfgren and Brunberg, 2004; Rengefors et al., 2004). Hence, it seems important to obtain more information on the spatial distribution of the resting stages in littoral bottom sediments, as well as the possible factors influencing the distribution. However, limited studies have attempted to quantify the resting stages in littoral sediments and to find the sites where resting stages accumulate constituting a «seed bank» for later bloom development. The purpose of the present study was to investigate the spatial distribution and seasonal dynamics of akinetes of cyanobacteria Anabaena flosaquae in a small Siberian reservoir to elucidate the process of akinete accumulation in littoral bottom sediments.

\section{The study site}

Bugach reservoir (locally called as Bugach pond) is situated $56^{\circ} 03^{\prime} \mathrm{N}$ and $92^{\circ} 43^{\prime} \mathrm{E}$ in the vicinity of the Krasnoyarsk city (Siberia, Russia) (Fig. 1). It is located in the Bugach river (secondary tributary of the Yenisei River). The reservoir has a surface area of about $0.32 \mathrm{~km}^{2}$, its maximum depth of $7 \mathrm{~m}$ and mean depth of about $2 \mathrm{~m}$. Water retention time in the reservoir is about 160 days. The reservoir is used for recreation and fishing. Detailed descriptions of the reservoir ecosystem are given elsewhere (Sushchik et al., 2004; Dubovskaya et al., 2003; Kalachova et al., 2004).

\section{Methods}

In order to investigate the distribution of akinetes in the littoral zone of the reservoir, samples of bottom sediments were taken in May and June 2002 (Fig. 1, stations denoted a) and on 16 October 2002 (Fig. 1, stations denoted b). Stations 1ab, 4a-6a and 7b-11b were located at the higher plant bed (see Table 1, 2). In April 2003 an additional sample was taken at a littoral station 3a (Fig. 1).

Four stations were sampled to study the seasonal dynamics of akinetes of A. flos-aquae in the reservoir (Fig. 1). Samples were taken weekly from May to September 2001-2004 at a site near the middle (central station 1; depth, ca. $4 \mathrm{~m}$ ) and in 2003-2004 in the littoral at the western shore (littoral station 2; depth, ca. 0.1-0.5 m). The site at western shore was chosen for regular sampling because it is located in open windward place and has no surface scums of bloom-forming cyanobacteria. In May-September 2004 samples were collected twice per month at a stream mouth at the west shore of the reservoir (littoral station 3; depth, ca. $0.5 \mathrm{~m}$ ) and at the east shore of the reservoir (station 4; depth, ca. $1.5 \mathrm{~m}$ ) (Fig. 1). Station 4 was at the leeward shore of the reservoir and accumulation of buoyant cyanobacterial populations might be expected from the prevailing north-westerly winds. Littoral stations 2 and 3 were located in a higher plant bed (Polygonium amphibium L. at station 2 and Typha latifolia L. at station 3). It must be stressed that some part of 


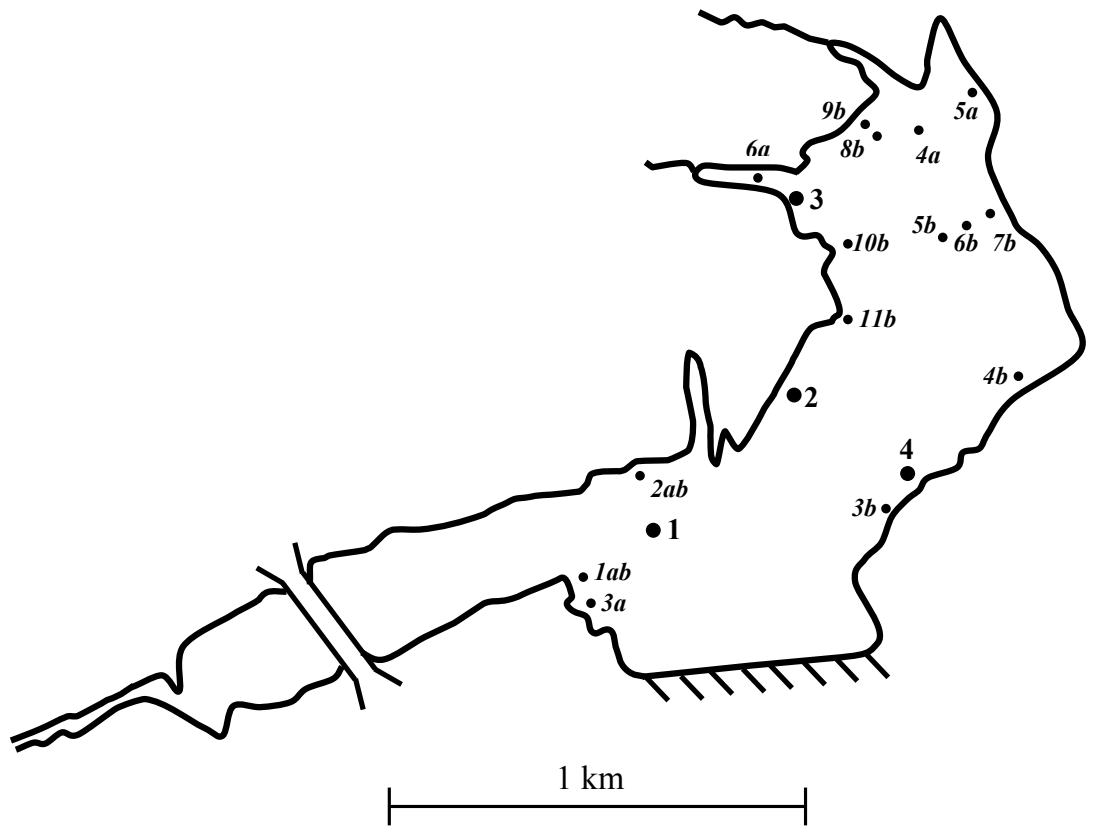

Fig. 1. Map of Bugach reservoir (Siberia, Russia) with the sampling sites. Letter a denotes spring sampling (MayJune) of 2002 and letter b denotes autumn sampling (16 October) of 2002

akinetes which is found in the water column of littoral stations were not produced at these sites but can be transported from the open part of the reservoir.

At the central station 1, water was sampled with an Ruttner-like sampler at 1-m intervals from the whole water column and pooled; in littoral stations 2-4 water was sampled with a bottle, which was dipped under water. Bottom sediments were sampled using a core sampler of $5 \mathrm{~cm}$ diameter. At stations 1-4 sediments were sampled in triplicate. At littoral stations 1ab-11b from one to three samples of bottom sediments were taken in May- June 2002 (see Table 1) and one sample on 16 October 2002.

Phytoplankton was concentrated by filtering $0.1 \mathrm{~L}$ of sample through cellulose filters «Vladipor» (Mytischi, Russia) (pore size 0.75$0.85 \mu \mathrm{m})$. The filters were placed in filtered reservoir water with Lugol's solution. Prior to enumeration in counting chamber cells were scraped from filters with scalpel. Then filter was carefully rinsed with distilled water. The abundances of vegetative cells of Anabaena flosaquae, akinetes (both attached to trichomes and free) in the water samples were determined using a Fuchs-Rosenthal counting chamber (0.0032 $\mathrm{ml}$ volume) under a light microscope at $400 \times$ magnification.

We sampled only the upper $1 \mathrm{~cm}$ of the sediments, that is, the top $1-\mathrm{cm}$ layer of each sediment core was placed in a $4-\mathrm{cm}$ diameter Petri dish and transported to the laboratory within an hour. Namely the upper layer of sediments is generally used for investigation of seasonal dynamics of resting stages (Baker, 1999; Kim et al., 2005; Kovacs et al., 2003). The changes in akinete abundance in the surface sediments reflect loss of germlings to the water column from germination and gain to the sediments from sporulation of the planktonic populaton. It has been shown, that equivalent changes in akinete abundance are generally not observed in the deeper layers of sediments (Baker, 1999).

All samples were stored in the dark at 4 ${ }^{0} \mathrm{C}$ until analysed within 2-3 days. Sub-samples 
Table 1. Abundance of akinetes of Anabaena flos-aquae in bottom sediments at littoral stations of the Bugach reservoir (Siberia, Russia) in May-June of 2002

\begin{tabular}{|c|c|c|c|c|c|}
\hline Date & Station & Replicates & $\begin{array}{c}\text { Predominant } \\
\text { bottom sediments }\end{array}$ & Predominant higher plants & $\begin{array}{c}\text { Akinete abundance, } \\
10^{3} \text { cells } / \mathrm{cm}^{2}\end{array}$ \\
\hline 15.05 .02 & $4 \mathrm{a}$ & 3 & silt & $\begin{array}{l}\text { Potamogeton perfoliatus L. } \\
\text { Potamogeton pectinatus L. }\end{array}$ & $20.711 \pm 7.858$ \\
\hline \multirow[t]{3}{*}{22.05 .02} & $1 \mathrm{ab}$ & 2 & silt & Typha latifolia $\mathrm{L}$ & $19.240 \pm 1.593$ \\
\hline & $5 \mathrm{a}$ & 1 & silt & $\begin{array}{l}\text { Phragmites australis (Cav.) Trin. ex } \\
\text { Steud } \\
\text { Potamogeton perfoliatus L. } \\
\text { Potamogeton pectinatus L. }\end{array}$ & 25.735 \\
\hline & $6 a$ & 2 & silt & Typha latifolia $\mathrm{L}$ & $9.681 \pm 3.554$ \\
\hline 29.05 .02 & $6 a$ & 3 & silt & Typha latifolia $\mathrm{L}$. & $10.417 \pm 1.621$ \\
\hline 5.06 .02 & $2 \mathrm{ab}$ & 2 & sand & - & n.f. \\
\hline 11.06 .02 & $3 a$ & 2 & sand & - & n.f. \\
\hline
\end{tabular}

n.f. - not found

Table 2. Abundance of akinetes of Anabaena flos-aquae in bottom sediments at littoral stations of the Bugach reservoir (Siberia, Russia) on 16 October 2002

\begin{tabular}{|c|c|c|c|}
\hline Station & $\begin{array}{c}\text { Predominant } \\
\text { bottom sediments }\end{array}$ & Predominant higher plants & $\begin{array}{c}\text { Akinete abundance, } \\
10^{3} \text { cells } / \mathrm{cm}^{2}\end{array}$ \\
\hline $1 \mathrm{ab}$ & silt & Typha latifolia $\mathrm{L}$. & 23.24 \\
\hline $2 \mathrm{ab}$ & sand & - & n.f. \\
\hline $3 b$ & sand & - & 2.45 \\
\hline $4 b$ & sand & $\begin{array}{l}\text { Potamogeton perfoliatus L. } \\
\text { Potamogeton pectinatus L. }\end{array}$ & 1.84 \\
\hline $5 b$ & sand & - & n.f. \\
\hline $6 b$ & sand & - & 3.68 \\
\hline $7 b$ & sand & $\begin{array}{l}\text { Phragmites australis (Cav.) Trin. ex } \\
\text { Steud }\end{array}$ & n.f. \\
\hline $8 b$ & silt & Typha latifolia $\mathrm{L}$. & n.f. \\
\hline $9 b$ & silt & Typha latifolia L. & 61.00 \\
\hline $10 \mathrm{~b}$ & silt & $\begin{array}{l}\text { Potamogeton perfoliatus L. } \\
\text { Potamogeton pectinatus L. }\end{array}$ & 20.33 \\
\hline $11 b$ & silt & Typha latifolia $\mathrm{L}$ & 17.43 \\
\hline
\end{tabular}

n.f. - not found

of $1.47 \mathrm{~cm}^{2}$ were cut with a tube corer from the samples and then suspended in $20 \mathrm{ml}$ of distilled water. This method is a modification of the techniques of number of authors (Head et al., 1998; Kovacs et al., 2003; Rasanen et al., 2006; Tsujimura and Okubo, 2003). A suitable dilution of the sediment is important for this technique, because in a concentrated sample the sediment particles often adhere to the akinetes, making them extremely difficult to identify. Prior to counting, the suspensions were shaken well in order to separate the sediment particles and the akinetes. The suspension was examined microscopically to identify and enumerate akinetes of $A$. flos-aquae, in the same way as in the phytoplankton samples. From one to eleven entire counting chambers were examined for samples from the central station 1 to count at least 50 akinetes. Five entire 


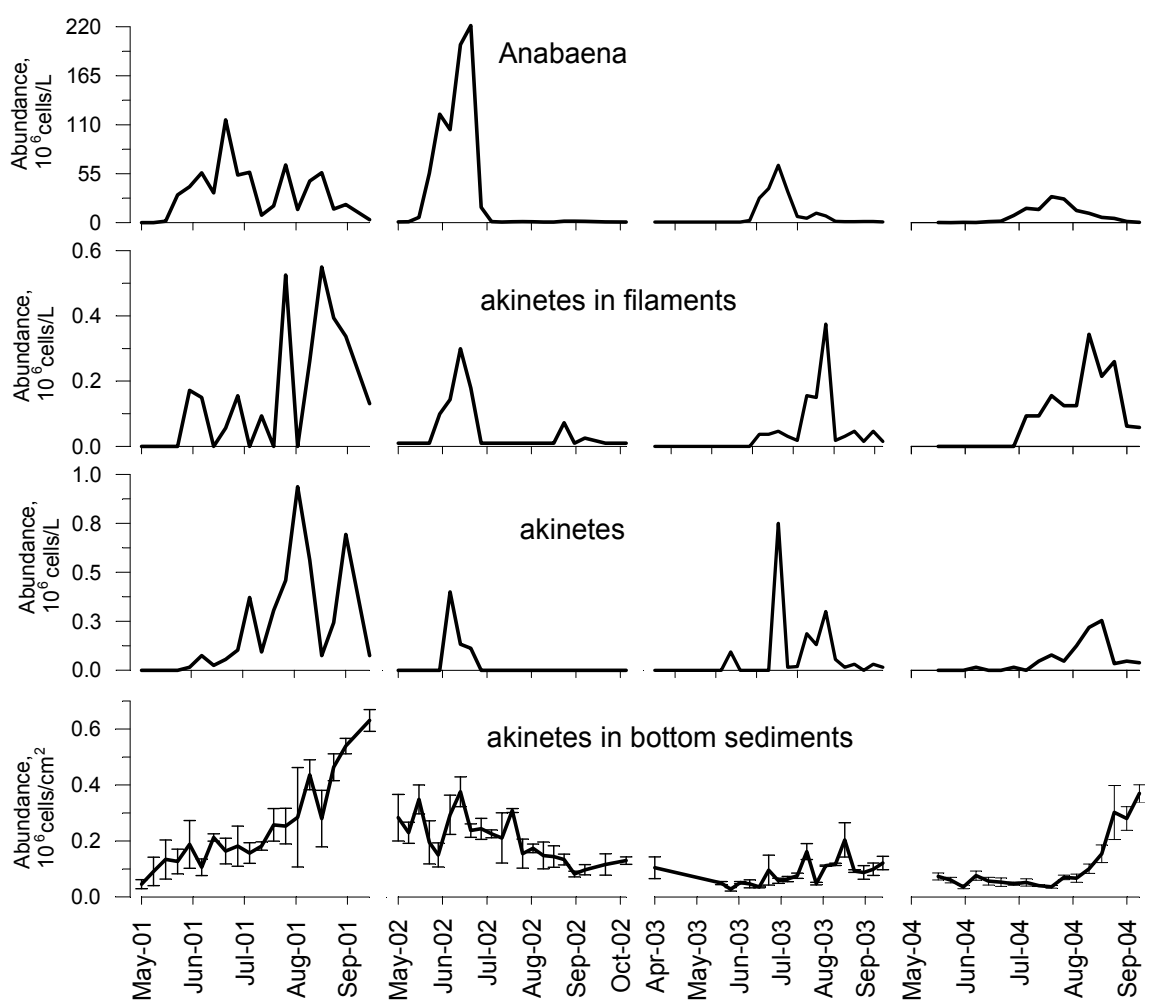

Fig. 2. Seasonal dynamics of abundance of Anabaena flos-aquae, akinetes (both attached and unattached to filaments) in water column and bottom sediments at the central station 1 of Bugach reservoir (Siberia, Russia) in April-October of 2001-2004. Error bars denote SE. Note different scales in y-axis

counting chambers were examined for samples from the stations 2-4 and from three to ten entire counting chambers were examined for samples from the littoral stations 1ab-11b. The results were expressed as number per $\mathrm{cm}^{2}$ in the upper $1 \mathrm{~cm}$ layer of sediments.

Standard errors (SE) and Student's $t$-test were calculated conventionally (Campbell, 1967).

\section{Results}

Akinete abundance in the upper layer of littoral bottom sediments in May - June and October 2002 is given in Tables 1 and 2. High abundance of akinetes (10-60 thousands per $\mathrm{cm}^{2}$ ) was observed at stations 1ab, 4a-6a and 9b-11b. In bottom sediments of other stations akinetes were absent or their abundance was markedly lower (2-4 thousands per $\mathrm{cm}^{2}$ ) (Tables 1,2$)$.
Dynamics of A. flos-aquae at the stations 1-4 in 2001-2004 is given in Fig. 2 and 3. In all four studied seasons at the station 1 abundance of $A$. flos-aquae in water started to increase at the end of May - beginning of June. In 2001 and 2004 abundance of the population was at the same level during whole summer, while in 2002 and 2003 in the second half of summer it decreased significantly. Dynamics of Anabaena abundance at the littoral stations 2-4 and the central station 1 were similar in 2003 and 2004, but number of cells at the littoral stations achieved a higher seasonal maximum than that at the station 1 (Fig. 2, 3).

In 2001-2003 akinetes in filaments appeared at the station 1 in the middle of June, while in 2004 - in the middle of July only (Fig. 2). In 2001, 2003 and 2004 they were observed in the water column during all the summer, but in 2001 


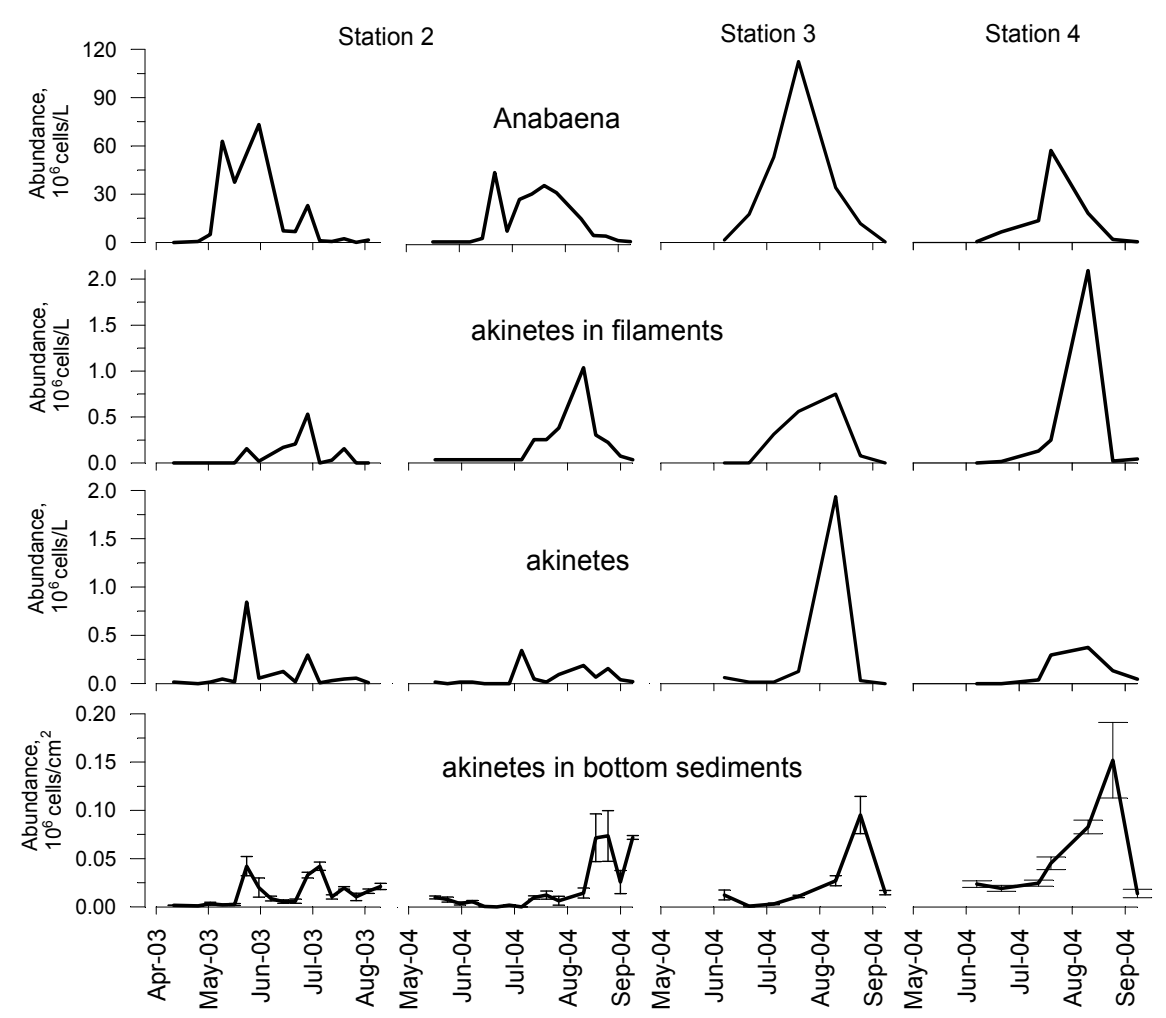

Fig. 3. Seasonal dynamics of abundance of Anabaena flos-aquae, akinetes (both attached and unattached to filaments) in water column and bottom sediments at littoral stations 2-4 of the Bugach reservoir (Siberia, Russia) in April-September of 2003-2004. Error bars denote SE. Note different scales in y-axis

their abundance periodically decreased down to zero. In these years maximum of abundance of akinetes in filaments occurred in August. In 2002 they had a seasonal peak in June and then they were absent in the water column until September. At the littoral stations 2-4 the dynamics of abundance of akinetes in filaments were similar to that at the central station in 2003 and 2004, but their maximum abundance at the littoral stations was higher than that at the central station (Fig. 2, 3).

During all three seasons akinetes were absent in the water column at the station 1 until the end of May - beginning of June (Fig. 2). In 2002 maximum abundance of akinetes at the station 1 occurred in June, while in 2001, 2003 and 2004 abundance of akinetes increased significantly in July and August. At the littoral stations in 2003 and 2004 akinetes also reached a seasonal maximum in the second half of summer, but at the station 3 it was much higher than that at the other stations (Fig. 2, 3).

Abundance of akinetes in bottom sediments at the station 1 increased during the seasons of 2001, 2003 and 2004 (Fig. 2). In 2002 number of akinetes in the bottom sediments tended to decrease to the end of season. Abundance of akinetes in sediments at the littoral stations was significantly lower than that at the central station (Fig. 2, 3). In littoral sediments peaks of akinete abundance took place in July of 2003 and in August of 2003 and 2004, but in both periods abundance of akinetes decreased just after increasing (Fig. 3).

During winter abundance of akinetes in bottom sediments at the central station 1 and at 
the littoral station 2 tended to decrease (Fig. 2, 3), but statistically significant $(t=7.38, p<0.05$ at d.f. $=4)$ difference was found only at the station 1 between the average values on 16 October 2002 and 21 May 2003. Additional samples, taken in littoral at the station 3a (Fig. 1), also demonstrated the winter decrease: in October 16, 2002 there were 23.24 thousands akinetes per $\mathrm{cm}^{2}$, while in April 2, 2003 there were only 1.23 thousands akinetes per $\mathrm{cm}^{2}$.

\section{Discussion}

Results of littoral sediment survey in May-June and October 2002 indicate that the abundance of akinetes was generally high in silty sediments (Table 1, 2; stations 1ab, 4a-6a, 9b-11b). In sandy sediments (stations 2ab, 3a, 3b-7b) akinetes were absent or their abundance was very low. This finding is similar to that of Tchernousova et al. (1968) who found that in bottom sediments of Dnieper reservoirs the highest abundance of cyanobacteria was observed in silt and minimal abundance - in sandy sediments. In the Murray River densities of Anabaena circinalis akinetes were also significantly higher in fine clay sediments in deeper water (11-15m) and lower in sediments of variable texture in water of 3-6 m depth (Baker, 1999). The lowest mean akinete densities were found in sandy substratum in shallow water (3m). Akinete densities in the lagoons of the Murray River were also generally higher in the deeper depressions of bottom characterized by fine-textured sediments. There is evidence that in sandy sediments akinetes may sink to deeper layers. Tchernousova et al. (1968) has shown that in silty sediments cyanobacterial maximum was observed in 2-3-cm layer, while in sandy sediments cyanobacteria was observed up to $12-18-\mathrm{cm}$ layer, due to of large mobility and filtration ability. Besides, akinetes can be lifted off the sediments by natural turbulence.
Resuspension of resting stages is likely more pronounced in sandy sediments than in silt.

On the otherhand, high abundance of akinetes in bottom sediments was observed at stations located in a macrophyte bed, consisting mainly of emerged higher plants Typha latifolia L. and Phragmites australis (Cav.) Trin. ex Steud (Table 1,2). It could be that the planktonic Anabaena population accumulates in the higher plants bed, and, therefore a higher number of akinetes deposits to sediments in this part of the reservoir in comparison with open littoral. Moreover, plants can prevent resuspension of resting stages from sediments. Generally, growth of macrophytes in a water body is considered as one of the measures to control bloom development because of their direct and indirect negative effects on cyanobacteria that include shading, zooplankton refuges and competition for nutrients (McQueen, 1990). There is evidence that some higher plants release allelopathic matters inhibiting growth of cyanobacteria (Nakai et al., 2000; Nakai et al., 2005). However, our results demonstrate that macrophytes beds could increase the size of the potential cyanobacterial inoculum by accumulation of akinetes in shallow bottom sediments and in this way favour cyanobacterial bloom development in deep water objects where recruitment of cyanobacteria can occur only from littoral sediments.

In autumn the akinete abundance in littoral sediments of the reservoir was at the same level as in the spring (Table 1,2), suggesting that there was no accumulation of resting stages during the vegetation season.

Comparison of the akinete densities in bottom sediments of different water bodies seems to be difficult due to the various method employed by researchers for quantification. The results are expressed as akinetes per gram of sediment (dry weight or wet weight), akinetes per milliliter of sediment, akinetes per $\mathrm{cm}^{3}$ of sediment. However, 
the order of $10^{4}$ akinetes $\mathrm{cm}^{-3}$ in the top layer of sediments has been considered to be typical for Anabaena akinete densities in water bodies where dense blooms have occurred (Tsujimura and Okubo, 2003; Faithfull and Burns, 2006; Head et al., 1998; Kim et al., 2005; Baker, 1999). Akinete densities in bottom sediments of Bugach reservoir are comparable with this value (Table 1, 2; Fig. 2, 3).

The abundance of akinetes in littoral sediments of the reservoir is much lower than that in the deeper (4 m) central part (Table 1, 2; Fig. 2, $3)$. It has been shown that resting stages accumulate in the sediment of mainly the profundal zone. For example, in Cauldshiels Loch (Scotland) total numbers of $A$. solitaria akinetes were generally lower in the shallow water sediments and higher in the deeper samples (Head et al., 1998). In bottom sediments of Dnieper reservoirs the highest abundance of cyanobacteria was observed at a depth of more than three meters and minimal abundance - at the shallow part of the reservoir (Vladimirova, 1968).

Dynamics of Anabaena abundance in the water at the central station and littoral stations were very similar, but number of cells at the littoral stations in the beginning of summer increased more rapidly and achieved higher year maximum than those at the central station (Fig. 2, 3). High abundance of Anabaena in the water column at littoral stations can be due to transport of cells from the open part of the reservoir. The highest abundance of akinetes in filaments in all stations was observed at the time when the planktonic population was decreasing, a week or more later after the population peak. The highest rate of akinete production during the late phase of the bloom often occurs in natural waters (Kondratyeva, 1975; Olli et al., 2005). In contrast, maximum akinete density of $A$. fos-aquae in the Murray River (Australia) and Seokchon reservoir (Korea) coincided with the population peak (Kim et al., 2005; Baker, 1999), as well akinetes of A. lemmermannii were produced, as the bloom progressed (Olli et al., 2005).

Percent proportion of the attached akinetes to vegetative cells (i.e. $A^{*} 100 / C$ where $A$ is attached akinetes and $\mathrm{C}$ is vegetative cells) can be used as an indicator of intensity of sporulation. In Bugach reservoir early in the season (June-July), when the population was increasing, the proportion was low and never exceeded $2.5 \%$. A few laboratory (van Dok and Hart, 1996), mesocosm (Olli et al., 2005) and field (Baker, 1999) studies have reported proportion of attached aknetes to vegetative cells or percentage of akinetes in total cells. The highest values in these studies (0.6-1.25\%) are comparable with that recorded in Bugach reservoir. Maximum proportion in the reservoir occurred by the end of the growth season (August- September) and comprised from $4 \%$ (2001) to $18 \%$ (2004) in open water. At the littoral stations 2 and 4 maximum proportion was of the same order and comprised $7 \%$ and $11 \%$. However the highest proportions coincided with the population decline and rather referred to the death of vegetative cells than akinete production intensity. Note that at the station 3 the proportion was only 1-2\% during all the season, suggesting low intensity of akinete production at this site.

Abundance of vegetative cells and unattached akinetes in water column at the central station 1 and the littoral stations 2 and 4 had comparable values (Fig. 2, 3). However, seasonal peak of abundance at the station 3, located in a Typha bed, was much higher than that at other stations, and confirms our suggestion on accumulation of akinetes in this part of the reservoir.

The dynamics of vegetative cells and akinetes in the water column was generally very similar in the open water and the littoral. Deposition of akinetes to bottom sediments also occurred both in open water and littoral (Fig. 2, 3). Nevertheless, akinete dynamics in bottom 
sediments differed between these two sites. At the central station accumulation of akinetes in bottom sediments occurred throughout the summer until September in all years except 2002 (Fig. 2). In littoral sediments akinete densities increased significantly in July of 2003 and in August of 2003 and 2004, and in both periods abundance of akinetes decreased just after their sedimentation (Fig. 3). P.D. Baker (1999) also has observed decrease in the akinete density of $A$. flos-aquae and $A$. circinalis in bottom sediments of the Murray River after their sedimentation. Since the decrease occurred at about the time of a second peak in the planktonic population, he has suggested that germination of akinetes took place at that period to maintain of planktonic population. In Bugach reservoir this explanation appears unlikely, however, because decrease of akinete abundance in bottom sediments was observed at the end of the growth season and Anabaena abundance in the water column significantly decreased. In Bugach reservoir decreases of akinete abundance just after their sedimentation in the littoral may be explained in two ways. On the one hand, it has been shown that accumulation of particles in littoral sediment may occur from the early till mid summer, then the cooling erodes the layer of accumulated materials and the particles are transported along the slope to deeper sediment (Verdouw et al., 1987). Thus, in Bugach reservoir akinetes could be transported from littoral to the sediments of deeper open water, as other particulate materials. On the other hand, akinetes may have smaller size than sediment particles and sink to deeper layers within sediments. As mentioned above, there is evidence that this process depends on sediment texture and it is more pronounced in sandy sediments than in silt (Tchernousova et al., 1968). The open water sediment of the Bugach reservoir is black silt, but there is sandy sediment in the considerable part of littoral. Therefore, decrease of akinete abundance in the littoral may be explained by their sinking to deeper layers of sediments.

It was found, that during winter abundance of akinetes decreased in bottom sediments both in littoral and deeper central parts of the reservoir (Fig. 2, 3). A similar decrease in akinete density has also been reported by Kim et al. (2005) in March-April in bottom sediments of Seokchon reservoir (Korea). These workers attribute this decrease to the akinetes germination in this period, even though development of planktonic population in the reservoir was delayed until in August. Causes of this phenomenon in Bugach reservoir are unknown. It may be supposed, that akinetes during winter can sink to deeper layers within sediments. Grazing by benthic invertebrates or (and) microbial attack may also decrease akinete density in bottom sediments.

\section{Conclusions}

Abundance of vegetative cells and akinetes of Anabaena flos-aquae in water column of the central deeper part of the reservoir was significantly lower than that in littoral. In contrast, akinetes densities in bottom sediments of open water were significantly higher than that in littoral. This discrepancy could be explained by different seasonal dynamics of akinetes in bottom sediments. Whereas the abundance of akinetes in open water sediments increased permanently during the growth season, in littoral akinete abundance decreased just after their sedimentation. The highest abundance of akinetes in littoral of the reservoir both in water and in bottom sediments were observed in a higher plant bed at sites with silty sediments. With regard to importance of akinetes as a seed bank for development of planktonic populations, such sites in a deep water bodies seem to be the main potential source of inoculum for the next season's bloom. 


\section{Acknowledgements}

The work was supported by grant No. RUX0-002-KR-06 of the U.S. Civilian Research $\&$ Development Foundation for the Independent States of the Former Soviet Union (CRDF) and the Ministry of Education and Sciences of Russian Federation, and at the stage of generalization -by «Thematic plans program» from the Ministry of Education and Sciences of Russian Federation (Theme B-4 of Siberian Federal University).

\section{References}

Baker P.D. (1999) Role of akinetes in the development of cyanobacterial populations in the lower Murray River, Australia. Mar. Freshwater Res. 50: 265-279

Campbell RC (1967) Statistics for Biologists. Cambridge University Press, Cambridge, UK

Dubovskaya O.P., Gladyshev M.I., Gubanov V.G., Makhutova O.N. (2003) Study of nonconsumptive mortality of Crustacean zooplankton in a Siberian reservoir using staining for live/dead sorting and sediment traps. Hydrobiologia 504: 223-227

Faithfull C.L., Burns C.W. (2006). Effects of salinity and source of inocula on germination of Anabaena akinetes from a tidally influenced lake. Freshwater Biology 51: 705-716

Head R.M., Jones R.I., Bailey-Watts A.E. (1998) Akinete germination and recruitment of planktonic cyanobacteria from lake sediments. Verch. Internat. Verein. Limnol. 26: 1711-1715

Head R.M., Jones R.I., Bailey-Watts A.E. (1999) An assessment of the influence of recruitment from the sediment on the development of planktonic populations of cyanobacteria in a temperate mesotrophic lake. Freshwater Biology 41: 759-769

Kalachova G.S., Kolmakova A.A., Gladyshev M.I., Kravchuk E.S., Ivanova E.A. (2004) Seasonal dynamics of amino acids in two small Siberian reservoirs dominated by prokaryotic and eukaryotic phytoplankton. Aquatic. Ecol. 38: 3-15

Karlsson-Elfgren I., Brunberg A.-K. (2004) The importance of shallow sediments in the recruitment of Anabaena and Aphanizomenon (Cyanophyceae). J. Phycol. 40: 831-836

Kim B.H., Lee W.S., Kim Y.O., Lee H.O., Han M.S. (2005) Relationship between akinete germination and vegetative population of Anabaena flos-aquae (Nostocales, Cyanobacteria) in Seokchon reservoir (Seoul, Korea). Arch. Hydrobiol. 163: 49-64

Kondratyeva N.V. (1975) Morphogenesis and main ways of evolution of the Hormogoniophyceae. Naukova dumka, Kiev, 150 p.

Kovacs A.W., Koncz E., Voros L. (2003) Akinete abundance of $\mathrm{N}_{2}$-fixing cyanobacteria in sediment of Lake Balaton (Hungary). Hydrobiologia 506-509: 181-188

Kravchuk E.S., Gladyshev M.I., Ivanova E.A. (2007) Dependence of the domination of Anabaena flos-aquae (Lyngb.) Breb. in the phytoplankton community on the initial abundance of akinetes. Doklady Biological Sciences 416: 377-378

McQueen D.J. (1990) Manipulating lake community structure: where do we go from here? Freshwater Biol. 23: 613-620

Nakai S., Inoue Y., Masaaki H., Murakami A. (2000) Myriophyllum spicatum - released allelopathic polyphenols inhibiting growth of blue-green algae Microcystis aeruginosa. Wat. Res. 34: 3026-3032

Nakai S., Yamada S., Hosomi M. (2005) Anti-cyanobacterial fatty acids released from Myriophyllum spicatum. Hydrobiologia 543: 71-78

$$
-246-
$$


Olli K., Kangro K., Kabel M. (2005). Akinete production of Anabaena lemmermannii and $A$. cylindrica (Cyanophyceae) in natural populations of N- and P-limited coastal mesocosms. J. Phycol. 41: 1094-1098

Paerl H.W., Fulton R.S., III, Moisander P.H., Dyble J. (2001) Harmful freshwater algal blooms, with an emphasis on cyanobacteria. The Scientific World 1: 76-113

Rasanen J., Kauppila T., Vuorio K. (2006) Sediment and phytoplankton records of the cyanobacterial genus Anabaena in boreal Lake Pyhajarvi. Hydrobiologia 568: 455-465

Rengefors K., Gustafsson S., Ståhl-Delbanco A. (2004) Factors regulating the recruitment of cyanobacterial and eukaryotic phytoplankton from littoral and profundal sediments. Aquatic Microbial Ecology 36: 213-226

Sirenko L.A. (1978) Some results of algophysiological researches at the Institute of Hydrobiology AS USSR. In: Problems of hydrobiology and algology. Naukova dumka, Kiev, p. 98-115

Sushchik N.N., Gladyshev M.I., Makhutova O.N., Kalachova G.S., Kravchuk E.S., Ivanova E.A. (2004) Associating particulate essential fatty acids of the $\omega 3$ family with phytoplankton species composition in a Siberian reservoir. Freshwat. Biol. 49: 1206-1219

Tchernousova V.M., Sirenko L.A., Arendarchuk V.V. (1968) Localization and physiological state of mass species of blue-greens algae in late autumn and spring periods. In: Topachevsky A.V. (ed.) Water bloom. Naukova dumka, Kiev, p. 81-91

Tsujimura S., Tsukada H., Nakahara H., Nakajima T., Nishino M. (2000) Seasonal variations of Microcystis populations in sediments of Lake Biwa, Japan. Hydrobiologia 431: 183-192

Tsujimura S., Okubo T. (2003) Development of Anabaena blooms in a small reservoir with dense sediment akinete population, with special reference to temperature and irradiance. Journal of Plankton Research 25: 1059-1067

van Dok W., Hart B.T. (1996) Akinete differentiation in Anabaena circinalis (Cyanophyta). J. Phycol. 32: 557-565

Verdouw H., Gons H.G., Steenbergen C.L.M. (1987) Distribution of particulate matter in relation to the thermal cycle in Lake Vechten (The Netherlands): the significance of transportation along the bottom. Water Research 21: 345-351

Vladimirova K.S. (1968) Interrelation between phytoplankton and phytomicrobenthos of reservoirs. In: Topachevsky A.V. (ed.) Water bloom. Naukova dumka, Kiev, p. 67-81 